Гращенко І.С., Краснюк М.Т., Кустаровський О.Д.

\title{
УДОСКОНАЛЕННЯ ЕКОНОМІКО-МАТЕМАТИЧНОГО МОДЕЛЮВАННЯ РЕЗУЛЬТАТІВ ВПРОВАДЖЕННЯ ОКРЕМИХ ЕЛЕМЕНТІВ АДАПТИВНОЇ АНТИКРИЗОВОЇ ПОЛІТИКИ КОМПАНІЙ ТРАНСПОРТНОЇ ГАЛУЗІ УКРАЇНИ
}

\begin{abstract}
В статті, з урахуванням вітчизняної національної специифіки, галузевої специфіки транспортної галузі та з урахуванням поточної політико-макроекономічної кризи, викладені результати досліджень щодо двох важливих $i$ взаємопов'язаних питань в контексті моделювання результатів впровадження адаптивної антикризової стратегії вітчизняних ТЕК, а саме: удосконалення очіночної моделі зміни результатів сукупного об'єктивного впливу зовнішніх кризових факторів та складових суб'єктивної антикризової політики на інтегрований результат логістичної діяльності підприємства; удосконалення оціночної моделі зміни загальних сформованих резервів/запасів ТЕК в рамках реалізаиії антикризових заходів ризик-менеджменту (що призведе до покращення його фінансової стійкості через можливість вивільнення частини сформованих резервів).
\end{abstract}

Ключові слова: транспортна галузь, криза, економіко-математичне моделювання, резерви, антикризова політика, кризові фактори, транспортно-експедиційна компанія.

Постановка проблеми. Сучасне світове ринкове господарство, яке характеризується такими процесами, як глобалізація ринків, інтернаціоналізація підприємств, бурхливий розвиток інформаційних технологій тощо, висуває підвищені вимоги до підприємств. Для виживання в умовах ринкової конкуренції вони мають мати здатність пристосовуватися до змін попиту, тобто повинні бути адаптивними. У стратегї розвитку України транспортна галузь відіграє одну 3 головних ролей. Безперебійно діюча система транспортних комунікацій $\epsilon$ основою, без якої відновлення стійкого економічного зростання країни неможливе. Проте існуючий стан в Україні однозначно можна характеризувати як системно та тотально кризовий, адже ще починаючи з 2009 року в економіці спочатку намітилось скорочення обсягів виробництва та реалізації продукції, пізніше, у 2011-2012 pp. розпочався період стагнації виробництва, а в 2013-2016 рр. під дією в т.ч. зовнішніх факторів, розвинулася системна політико-парамілітарно-економічна системна криза, яка кумулятивно та драматично додатково вплинула на стан вітчизняної

(C) Гращенко Ірина Семенівна, к.е.н., доцент, Національний авіаційний університет, м. Київ, тел.: 0974462090, email: irylj@ukr.net

Краснюк Максим Тарасович, к.е.н., доцент, Київський національний економічний університет ім. Вадима Гетьмана, м. Київ, тел.: 0677560700, email: kmt@ukr.net

Кустаровський Олександр Дмитрович, аспірант, Київський національний економічний університет ім. Вадима Гетьмана, м. Київ, тел.: 0939531985, email: kust19921987@gmail.com транспортної галузі.

Тому, враховуючи національну, макроекономічну, галузеву специфіку задачі реінжинірингу вітчизняних транспортноекспедиційних компаній в умовах кризи, $\epsilon$ актуальними весь комплекс досліджень щодо моделювання результатів впровадження адаптивної антикризової стратегії вітчизняних TEK.

Аналіз останніх досліджень і публікацій Теоретико-методологічним та практичним питанням побудови та застосування економікоматематичних моделей $\mathrm{y}$ процесах антикризового управління було приділено значну увагу такими українськими науковцями як Вітлінський В.В., Камінський А. Б., Клебанова T.С., Матвійчук А.В., Негрей М.В., Черняк О.I., Шарапов О.Д., Ящук Д.В. та іншими, а також іноземними дослідниками Р.Айзенбайсом, Е.Альтманом, У.Бівером, Т.К.Богдановою, К.Завгрен, В.В.Ковальовим, Т.Королем, Г. Лі, Дж. Ольсоном, М.Ф. Салахієвою, Д. Суном та іншими. Дослідження антикризового управління в транспортній факторі змістовно викладено в роботах Бакаєва О.О., Вороніної О.С., Воєнної К.І., Гавриленка Т.В., Ковальчука Н.О., Кравчука Л.С., Міщенко М.І., Павлюка А.О., Прядуна Є.А., Фучеджи B.I., Сич Є.М. проте не розкрито питання специфіки антикризового управління 3 урахуванням традиційної вітчизняної макроекономічної специфіки, стадії поточної кризи української економіки та галузевої специфіки транспортної галузі.

Формулювання цілей статті. У процесі триваючої адаптації національної економіки України до глобальних змін у світовій економіці 
у контексті подальшої інтеграції до $€ C$, у контексті поточної форс-мажорної української політико-макроекономічної кризи (що переросла за останні 3 роки у системну) удосконалення логістичного менеджменту 3 урахуванням вищенаведених впливів $\epsilon$ вкрай важливим та актуальним інструментом приватних та державних компаній. Тобто актуальним i невирішеним дотепер залишається весь спектр питань розробки комплексної концепції антикризового логістичного менеджменту, відповідного економіко-математичного та інформаційного забезпечення в умовах українських кризових системних явищ.

Опис основного матеріалу дослідження. Аналіз динаміки ємності транспортної галузі України у ВВП свідчить про зменшення обсягів перевезень, до яких відносяться: падіння обсягів готової продукції промислового виробництва в Україні та зниження обсягів внутрішнього попиту 3 причини зменшення купівельної спроможності, про що свідчить отримана динаміка показників вітчизняної транспортної галузі (див. рис. 1).

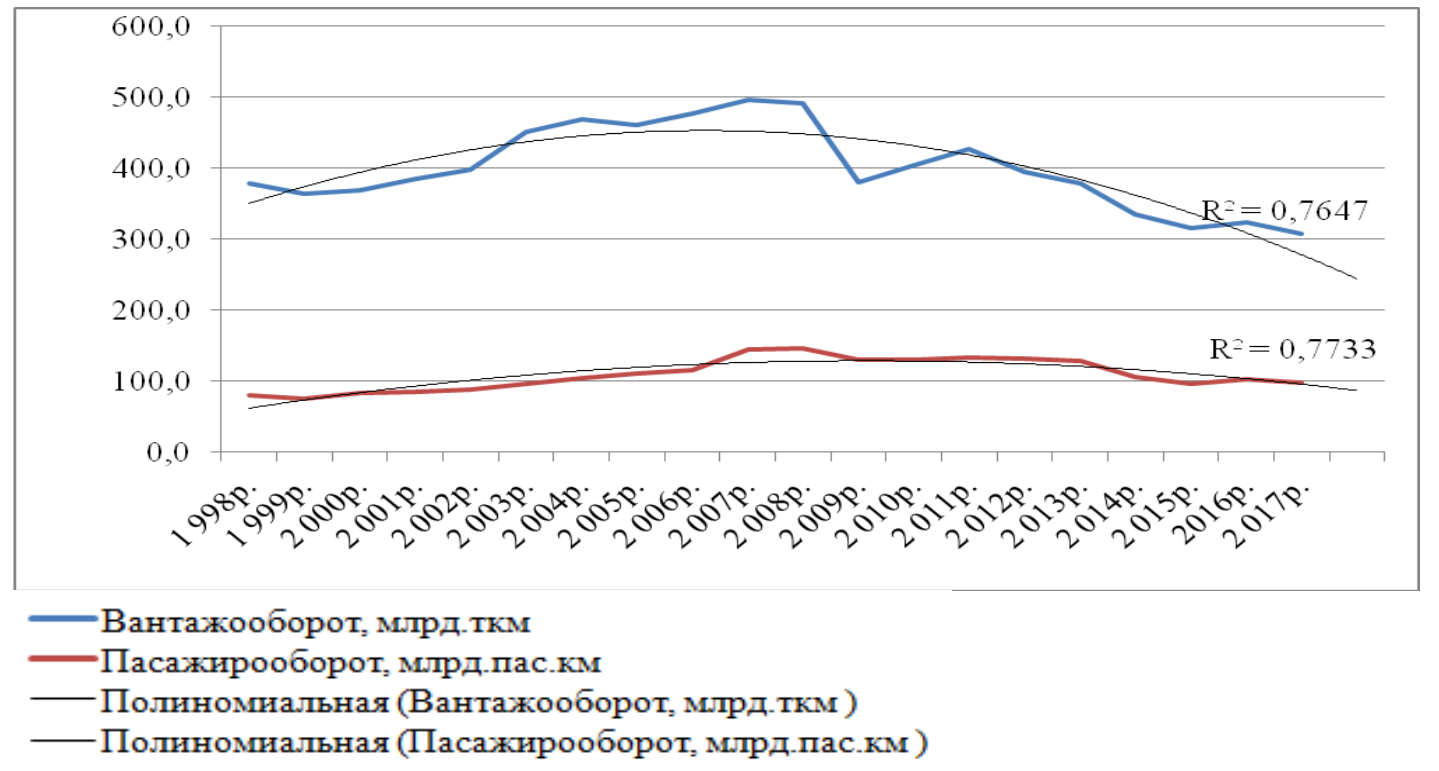

Рис. 1. Динаміка вантажообороту та пасажирообороту 1998-2017pp.*

* Розроблено авторами за джерелом [1,2]

Безперечно (що показує статистичні тренди), початок кризової стагнації вітчизняної транспортної галузі був викликаний не вищезгаданими форс-мажорними чинниками, а впливом ранжованих факторів, що системно стримують роботу транспортних підприємств: податкова система, конкуренція 3 боку вітчизняних перевізників, застарілий парк транспортних засобів, низький платоспроможний попит, нестача оборотних коштів, нестача запчастин, комплектуючих, нестача транспортних засобів, нестача паливних, мастильних матеріалів. Фінансові обмеження, недостатній попит та інші чинники ще до кризи 2013-2014 років приводили до дестабілізізації бізнес ситуації в галузі, що в свою чергу призводило до відсутності позитивних зрушень у фінансово-економічному стані транспортних підприємств. Збільшення загального обсягу інвестицій та зменшення впливу чинників, що обмежують інвестиції, а саме високі процентні ставки за кредитами, труднощі 3 отриманням довгострокових кредитів та нестача власних коштів могли раніше сприяти покращення ситуації в галузі.

Проаналізуємо детальніше динаміку кризового стану вантажних перевезень. За 2000р. перевезено 672,1 млн тонн вантажів, вантажооборот досяг 369,2 млрд тоннокілометрів і зріс на 1,3\%. Збільшення обсягів транспортної роботи відмічено, насамперед, на залізничному, автомобільному та річковому транспорті. Зростання вантажних перевезень на залізничному транспорті досягнуто внаслідок проведення цілеспрямованої гнучкої тарифної політики - надання знижок тарифів в залежності від конкурентоспроможності напрямку, роду вантажу і його вартості та обсягів транзитних вантажних перевезень. За 2001 рік підприємствами транспорту перевезено 752,1 млн тонн вантажів, що на $0,8 \%$ більше, ніж за 2000 рік, вантажооборот зріс на 1,0\% і склав 384,5 млрд тонно-кілометрів. На автомобільному транспорті зберігається тенденція збільшення обсягів міжобласних та міжнародних перевезень. Вантажооборот автомобільного транспорту зріс 
на 7,1 \% і досяг 8,2 млрд ткм. [3].

Період 2013-2014 рp. характеризується такими змінами в результатах діяльності підприємств транспортної галузі: відбулося зменшення обсягів виконуваних транспортними підприємствами робіт і послуг, спостерігається зниження попиту на транспортні роботи та послуги, підвищення рівня достатності виробничих потужностей транспортних підприємств для виконання ними робіт і послуг, суттєві зміни у ціновій політиці на виконання транспортних робіт і послуг, посилення впливу на роботу підприємств таких факторів, як конкуренція 3 боку вітчизняних перевізників, високі податки, застарілий парк транспортних засобів, низький платоспроможний попит i нестача оборотних коштів, зменшення кількості працівників. зменшення загального обсягу інвестицій. За 2014 рік капітальні інвестиції підприємств за видами економічної діяльності "Наземний i трубопровідний транспорт", "Водний транспорт", "Авіаційний транспорт" становили 4,5 млрд грн проти 5,2 млрд грн за 2013 рік.

Все це призводить до погіршення фінансовоекономічного стану транспортних підприємств. За 2014 рік сальдований фінансовий результат до оподаткування (попередні дані) підприємств за видом економічної діяльності "Транспорт, складське господарство, поштова та кур'єрська діяльність" становив 16,7 млрд грн збитків, що у 2,3 раза більше, ніж за 9 місяців 2014 року $(7,3$ млрд грн) [3].

У 2014 році спостерігається зниження вантажних перевезень, у порівнянні 32013 роком, залізничним транспортом на 4,5\%, автомобільним на $5,1 \%$, трубопровідни на $26,4 \%$, авіаційним на $11,7 \%$ і лише водним транспортом перевезення збільшились на 18,5\%. [3]. Така тенденція скорочення спостерігалась і у 2015 році: скорочення перевезень залізничним транспортом на 7,5\%, автомобільним на $8,8 \%$, трубопровідни на $1,1 \%$, авіаційним на $11,8 \%$ i лише водним транспортом перевезення збільшились на $1 \%$. Загальний обсяг вантажообороту всіма видами транспорту у 2015 році становив 215,3 млд ткм. що на $6 \%$ менше за 2014 рік. [1].

У 2016 році ситуація дещо покращилась, тенденція до збільшення транспортних перевезень спостерігається у автомобільному, трубопровідному та авіаційному транспорті. У 2016р. вантажооборот підприємств транспорту становив 323,5 млрд.ткм, або $102,4 \%$ від обсягу 2015p. Підприємствами транспорту перевезено 624,5 млн т вантажів, що становить $103,8 \%$ від обсягів 2015p. [1].
У 2016р. вантажооборот підприємств, що експлуатували автомобільний транспорт (власний або орендований), становив 41,9 млрд.ткм ${ }^{1}$, 3 нього у міжнародному сполученні 9,4 млрд.ткм. [3]. Обсяг перевезених вантажів підприємствами, що експлуатували автомобільний транспорт, склав 1,0 млрд т вантажів, або $106,1 \%$ від обсягів 2015p.

Обсяги експорту товарів у 2016p. за видами їх транспортування розподілялися так: морськими суднами перевезено 51,1\% від загального обсягу експорту товарів, вантажними автомобілями $24,3 \%$ та залізничними вагонами $-12,3 \%$. Серед основних видів транспорту, яким ввозились товари в Україну, значна частка припадала на вантажні автомобілі - 47,0\%, залізничні вагони $16,6 \%$, контейнери на морських суднах $-12,1 \%$.

у 2017p. вантажооборот підприємств транспорту становив 339,3 млрд тонн, або 98,9\% від обсягу 2016р. [4] Підприємствами транспорту перевезено 467,0 млн т. вантажів, що становить 102,8\% від обсягів 2016р., за січень грудень 2017 року перевезено 339,55млн т. вантажу [3].

Проаналізуємо стан та динаміку пасажирських перевезень. Обсяги перевезень пасажирів залізничним транспортом зросли на $2,4 \%$, морським - на $21,9 \%$, авіаційним транспортом - на 7,6\%, кількість перевезених пасажирів у 2017 в порівнянні 32016 роком збільшилось на 32,2\%.[5] Помітно підвищилася якість обслуговування населення в більшості міст та селищ країни завдяки обмеженню монополізму на ринку пасажирських автомобільних перевезень та створенню конкурентного середовища, в якому суб'єкти малого бізнесу юридичні та фізичні особи зайняли своє місце i виконують чверть маршрутних автоперевезень. В цілому автомобільним транспортом перевезено 2,6 млрд. пасажирів, пасажирооборот досяг 30,0 млрд. пас-км, що, відповідно, на 4,8\% та 10,3\% більше попереднього року.

За 2001 рік всіма видами транспорту перевезено 3,2 млрд пасажирів, виконано пасажирську роботу в обсязі 85,5 млрд пас.км, що відповідно на 2,7 \% та на 2,3 \% більше, ніж за 2000 рік. [2].

Пасажирські перевезення за 2013 рік всіма видами транспорту мають таке значення показника 6,62 млд пас., що по відношенню до 2012 року знизилось $2,8 \%$.

У 2014 році пасажирські перевезення всіма видами транспорту мають значення показника 5,89 млд пас., що по відношенню до 2013 року знизилось $5,3 \%$. Це вказує що криза транспортної галузі поглиблюється. [3].

Для пасажирських перевезень за 2015 рік всіма видами транспорту значення показника 
знизилось 12,3\% по відношенню до 2014 року та склав 5,17млрд пас. [2].

У 2016p. усіма видами транспорту виконано пасажирооборот в обсязі 102,2 млрд пас.км, що становить $105,4 \%$ від обсягу 2015 p. У січні - вересні 2017p. усіма видами транспорту виконано пасажирооборот в обсязі 74,6 млрд пас.км, що становить $108,0 \%$ від обсягу січня - вересня 2016p. Послугами пасажирського транспорту скористалися 3447,2 млн пасажирів, або 100,2\% від обсягу січня - вересня 2016p. [2].

Враховуючи вищенаведене, удосконалення економіко-математичного моделювання антикризового управління в транспортній галузі, має забезпечувати адекватну та системну мультимодальну реакцію на вищезгадані кризові явища.

Антикризове управління - це спеціальне, постійно організоване управління, націлене на найбільш оперативне виявлення ознак кризового стану та створення відповідних передумов для його своєчасного подолання 3 метою забезпечення відновлення життєздатності окремого підприємства, недопущення виникнення ситуації його банкрутства [7].

Формування антикризової програми належить до найбільш відповідальних та вагомих питань, оскільки саме обгрунтований вибір антикризових заходів забезпечує виведення підприємства зі стану кризи 3 найменшими втратами у найкоротші терміни. [6].

Теоретичні питання та методичні аспекти визначення змісту антикризової програми, тобто оптимального переліку антикризових заходів та послідовності їх реалізації, належать до найменш розроблених.

В сучасних вітчизняних макроекономічних та галузевих умовах (див. вище), важливим $\epsilon$ формулювання антикризової логістичної стратегіï (та проектування відповідної логістичної системи) із врахуванням поточного стану галузі, регіону та конкретної ТЕК.

Надалі будуть викладені результати досліджень щодо двох важливих і взаємопов'язаних питань в контексті моделювання та/або аналізу результатів впровадження адаптивної антикризової стратегії вітчизняних ТЕК, а саме:

- удосконалення оціночної моделі зміни результатів сукупного об'єктивного впливу зовнішніх кризових факторів та складових суб'єктивної антикризової політики на інтегрований результат логістичної діяльності підприємства;

- удосконалення оціночної моделі зміни загальних сформованих резервів/запасів ТЕК в рамках реалізації антикризових заходів ризикменеджменту (що призведе до покращення його фінансової стійкості через можливість вивільнення чистини сформованих резервів).

Отже, розглянемо спочатку першу модель.

Важливою складовою антикризової стратегії логістичної діяльності $є$ можливість планувати (через попереднє моделювання) результат зміни результуючих інтегрованих показників логістичної діяльності в залежності від дії кризових чинників як мікросередовища $\mathrm{i}$ зовнішнього макросередовища.

Тобто пропонується моделювати зміну результатів $\triangle I N F$ сукупного об'єктивного впливу зовнішніх кризових факторів та складових суб' єктивної антикризової політики на інтегрований результат логістичної діяльності підприємства. А як результат антикризового менеджменту треба розглядати не просто зміну доходу, прибутку, рентабельності, а зміну прогнозного показника інтегрованої фінансової стійкості через наступну удосконалену модель:

$\Delta I N F=\sum_{i=1}^{m} k_{i}$ ext $_{i}+\sum_{j=1}^{n} k_{j} i n t_{j}+\sum_{i=1}^{m} \sum_{j=1}^{n} k_{i j}$ cum $_{i j}$

де:

int $_{j}$ - зміна результативного показника логістичної діяльності підприємства за рахунок $i$ того кризового чинника мікросередовища;

ext $t_{i}$ - зміна результативного показника логістичної діяльності підприємства за рахунок $j$-того кризового чинника зовнішнього макросередовища;

cum $_{i j}$ - зміна результативного показника логістичної діяльності підприємства за рахунок опосередкованого впливу і-того чинника мікросередовища через $\mathrm{j}$-ий чинник зовнішнього мікросередовища;

причому, $k=[0 ; 1], k=0$ - якщо впливом кризового чинника можна нехтувати при моделюванні, a $k=1$ - коли вплив кризового чинника треба враховувати в моделюванні в повній мірі. Його конкретне значення для моделювання конкретної діï чинників ризику пропонується визначати згідно методології нечіткого логічного висновку в рамках експертного аналізу з використанням бази знань ЛІС та/або нечітких ad-hoc кейсів.

Адекватність отриманих результатів логістичного моделювання залежить не тільки від достовірності джерела, але й від репрезентативності даних вибірки, їх оцінки, перевірки, fraud detection, але і адекватної інтерпретації [8]. Із цією метою слід, після проведення факторного аналізу, провести формування ієрархічних кластерів кризових показників. Критеріями вибору показників виступають не тільки їх вплив (у випадку 
внутрішніх кризових факторів) при антикризовому менеджменті на обраний інтегрований цільовий показник, але і найбільш повне віддзеркалення дії зовнішніх кризових факторів середовища. Таке моделювання буде специфічним для кожного конкретного підприємства в умовах кризи, зокрема воно має враховувати не тільки фазу кризи, але і рольову функцію підприємства у випадку наявності логістичної кооперації.

I3 урахуванням вищевикладеного, наведемо результати досліджень щодо другої оціночної моделі, яка може бути використана в якості складової до першої.

3 точки зору антикризової стратегії логістичної діяльності забезпечення економічної безпеки через розробку методики та технології управління відповідними ризиками важко переоцінити.

Економічна безпека динамічна категорія, тому вона вимагає постійного моніторингу i мікро-, i макросередовища і має розглядатися залежно від умов функціонування підприємства [9]:

- у звичайних умовах може йтися про економічну стійкість, яка визначається фінансовим положенням, конкурентоспроможністю продукції (послуги) і підприємства в цілому. Економічну загрозу тут можуть являти: активна частина основних фондів (моральний знос), нова технологія (убудованість у виробничий процес), персонал (спеціалізація і кваліфікація) та ін.;

- в екстремальних умовах центром уваги мають стати захисні заходи проти агресивного зовнішнього середовища, спрямовані на зниження потенційного господарського ризику.

У разі одночасного настання розглянутих вище внутрішніх системних та зовнішніх екстремальних кризових умов, імовірність «краху» підприємства наближається до одиниці. Особливо це стосується невеликих підприємств, що не мають необхідного запасу стійкості.

Отже, викладемо основні складові системи забезпечення економічної безпеки логістичної діяльності:

- Фінансова складова (наприклад: підвищення фінансової стійкості за рахунок засобів, що раніше витрачалися на конкурентну боротьбу між учасниками процесу руху товару; зменшення фінансових втрат у вигляді штрафів у зв'язку 3 переходом відносин між підприємствами на новий рівень, що $є$ співпрацею учасників єдиного логістичного процесу тощо);

Технологічна складова (наприклад: патентний захист нових технологій тощо);

Організаційна складова (наприклад: фізичний захист матеріально-технічної бази i персоналу тощо);
- Інформаційна складова (наприклад: впровадження заходів захисту інформації тощо).

У світовій практиці до 50\% комерційних операцій зазнають невдачі через недостатню увагу до проблеми ризиків. Ризики в логістичному менеджменті можуть походити від внутрішніх та зовнішніх чинників. Систематизувавши всі класифікаційні ознаки, можна виділити наступні основні групи ризиків в процесі функціонування логістичних систем: політичні, макроекономічні, комерційні, ризики реалізації, ризики митного оформлення, транспортні [10].

Проведений аналіз причин виникнення та систематизація результатів оцінки логістичних ризиків, як правило, дозволяють надалі прийняти рішення про заходи компенсації, зниження або запобігання ризиків логістичної діяльності. В основі таких заходів лежать існуючі та постійно адаптовані методи. До їх числа можна віднести наступні:

1. Диверсифікація - розподіл інвестуємих коштів між різними об'єктами вкладення капіталу в ЛС, які безпосередньо не пов'язані між собою, що сприяє зниженню ризику і зменшення втрат.

2. Передача ризику (зниження ризику) передавальна сторона (трансферу) передає ризик приймаючій стороні (трансфер) на основі укладання контракту. Широко застосовується при укладанні будівельних контрактів, оренду, лізинг, в договорах зберігання, перевезення, продажу, обслуговування, постачання, доручення, факторингу (під уступку грошової вимоги), біржових угодах.

3. Лімітування - встановлення граничних сум витрат, продажу, кредиту і т.п. Використовується банками при видачі позик, підприємствами при продажу товарів у кредит, інвесторами при визначенні сум вкладень капіталу. Лімітування може розглядатися і як метод обмеження ризику.

4. Страхування - передача або розподіл ризиків, що виникають у однієї особи, між низкою осіб. Використовується відповідно до чинного законодавства в різних країнах - подвійне страхування, перестрахування, самострахування.

5. Усунення ризику - відмова від деяких видів діяльності, пов'язаних з ризиком.

6. Виявлення додаткових закономірностей 3 використанням KDD 3 метою зменшення інформаційної невизначеності.

Безпосередньо та терміново певним чином зменшує ризик 5-ий чинник, оскільки перший та другий чинники - розподіляють ризик між видами продукції і суб'єктами відповідно, а четвертий - передає його страховій компанії. Отже, диверсифікація, що є розширенням асортименту продукції (послуг), дозволяє отримати середній 
дохід, знижуючи ймовірність як максимального, так i мінімального доходу. А лімітування знижує (лімітує) не тільки ймовірні втрати, але i майбутні потенційні прибутки. Саме різниця між ними практично і $є$ платою за зниження ризику. У решті випадків плата за ризик має реальний кількісний вимір: оплата страховки або вартість придбаної інформації.

Заходи зі зниження економічного ризику в рамках антикризової політики транспортного підприємства в кінцевому підсумку можуть вести до покращення його фінансової стійкості через можливість вивільнення чистини сформованих резервів (запасів):

$$
\begin{aligned}
\triangle R E Z=R E Z_{t} & -R E Z_{t+1} \\
& =\left(\sum_{i=1}^{I} \Delta p_{i t} r e z_{i} k m_{i}+\sum_{j=1}^{j} \Delta p_{j t} r e z_{j}\right) \\
& -\left(\sum_{i=1}^{I} \Delta p_{i t+1} r e z_{i} k m_{i}+\sum_{j=1}^{j} \Delta p_{j t+1} r e z_{j}\right)
\end{aligned}
$$

$k m_{i}$ - коефіцієнт мультиплікації сформованих резервів під $i$-ий вид економічного ризику, що значно залежить від результатів аудиту, специфіки конкретної транспортної компанії та цілей прийнятої антикризової стратегії, і який пропонується визначати експертним чином;

$R E Z_{t}$ - сума загальних сформованих резервів/запасів в рамках політики ризикменеджменту в часовий період $t$;

$\Delta p_{i t}-$ зміна ймовірності настання одиничного ризику і в рамках часового періоду $\mathrm{t}$;

$\Delta p_{j t}$ - зміна ймовірності настання групового (синегітичного) ризику $j$ в рамках часового періоду $t$.

До запропонованої вище моделі слід додати наступні пояснення:

- групування ризиків у синергітичні групи j здійснюється експертним шляхом (сформованим антикризовим комітетом) по результатах аудиту та фін. аналізу транспортної компанії та 3 урахуванням прийнятої антикризової стратегії;

- ініціалізація показників $p$, rez та $\mathrm{km}$ відбувається на третьому етапі антикризової політики, здійснюється експертним шляхом (сформованим антикризовим комітетом) по результатах аудиту та фін. аналізу транспортної компанії та 3 урахуванням прийнятої антикризової стратегіі;

- в разі значної та/або систематичної зміни $\Delta r e z$ в період $t+1$ - необхідна зміна початково встановлених значень $r e z$ та $k m$ експертним шляхом на базі проведеного статистичного аналізу

\section{Висновки i перспективи подальших} досліджень Вищевикладені результати удосконалення економіко-математичного моделювання антикризового управління в транспортній галузі, зокрема щодо моделювання та/або аналізу результатів впровадження адаптивної антикризової стратегії вітчизняних TЕК, дозволять забезпечувати адекватну та системну мультимодальну реакцію на вищезгадані кризові явища.

Адекватність отриманих результатів логістичного моделювання залежить не тільки від достовірності джерела, але й від репрезентативності даних вибірки, їх оцінки, перевірки, fraud detection, але i адекватної інтерпретації. Із цією метою слід, після проведення факторного аналізу, провести формування ієрархічних кластерів кризових показників. Критеріями вибору показників виступають не тільки їх вплив (у випадку внутрішніх кризових факторів) при антикризовому менеджменті на обраний інтегрований цільовий показник, але і найбільш повне віддзеркалення дії зовнішніх кризових факторів середовища. Таке моделювання буде специфічним для кожного конкретного підприємства в умовах кризи, зокрема воно має враховувати не тільки фазу кризи, але і рольову функцію підприємства у випадку наявності логістичної кооперації.

Отримані результати можуть бути використані як вітчизняними транспортноекспедиційними компаніями, так i іноземними компаніями на іноземних ринках країн, що розвиваються та/або знаходяться під впливом аналогічних політико-макроекономічних кризових явищ (наприклад, деякі країни колишнього СРСР, північної Африки та близького сходу). Отримані результати є основою для подальших досліджень 3 питань економіко-математичного моделювання логістичної діяльності підприємств транспортної галузі в умовах системної української економікополітичної кризи, розвитку українських логістично-інформаційних систем та будуть в перспективі проведені авторами при подальших дослідженнях в цій сфері.

\section{ПЕРЕЛІК ВИКОРИСТАНИХ ДЖЕРЕЛ}

1. Вантажооборот та обсяги перевезень вантажів / [Електронний ресурс] // Держстат України. - 2017. Режим доступу до ресурсу: http://www.ukrstat.gov.ua/operativ/operativ2017/tr/vp/vp_u/vp1217_u.htm

2. Пасажирооборот та кількість перевезених пасажирів / [Електронний ресурс] // Держстат України. - 2017. 
- Режим доступу до ресурсу: http://www.ukrstat.gov.ua/operativ/operativ2017/tr/pp/pp_u/pp1217_u.htm

3. Транспорт [Електронний ресурс] // Держстат України. - 2017. - Режим доступу до ресурсу: http://www.ukrstat.gov.ua/operativ/operativ2005/tz/tz_rik/tz_u/ts_u.htm

4. Статистичні дані про Українські залізниці / [Електронний ресурс] // Міністерство інфраструктури України. - 2017. - Режим доступу до ресурсу: https://mtu.gov.ua/content/statistichni-dani-pro-ukrainskizaliznici.html

5. Статистичні дані в галузі авіатранспорту / [Електронний ресурс] // Міністерство інфраструктури України. - 2017. - Режим доступу до pecypcy: https://mtu.gov.ua/content/statistichni-dani-v-galuzi-aviatransportu.html

6. The development of the concept and set of practical measures of anti-crisis logistics management in the current Ukraine conditions / Maxim Krasnyuk, Oleksandr Kustarovskiy // Zarządzanie. Teoria i Praktyka 19 (1) 2017 P. $31-39$. [Електронний ресурс]. - режим доступу: http://www.kaweczynska.pl/wydawnictwo/zarzadzanie-teoria-ipraktyka/zarzadzanie-teoria-i-praktyka-numer-biezazy?download=5464:zarzadzanie-teoria-i-praktyka-managementtheory-practice-4-18-2016

7. Антикризовий менеджмент як інструмент недопущення загрози банкрутства / Л. С. Кравчук, К. І. Воєнна / - [Електронний pecypc]. - режим доступу: http://www.m.nayka.com.ua/?op=1\&j=efektyvnaekonomika\&s=eng\&z=1089

8. М.Т. Краснюк, О.Д. Кустаровський «Проблеми та перспективи розвитку українських логістичноінформаційних систем в умовах глобалізованої економіки та макроекономічних кризових явищ» // Інвестиції: практика та досвід №10, 2017: Чорноморський державний університет імені Петра Могили, с. 34-40.

9. Судакова О. Логістизація як засіб забезпечення економічної безпеки підприємства / О. Судакова // Схід.2008 p.-№ 3(87)

10. Гапчак Т.Г. Ризики в логістичних процесах [Текст] / Т.Г. Гапчак // Економіка: проблеми теорії та практики. - 2010. - № 262. - [Електронний ресурс]. - режим доступу: http://socrates.vsau.org/repository/getfile.php/4188.pdf

\section{REFERENCES}

1.Vantazhooborot ta obsiahy perevezen vantazhiv. Derzhstat Ukrainy [Cargo turnover and volumes of cargo transportation. Gosstat of Ukraine]. ukrstat.gov.ua Retrieved from: http://www.ukrstat.gov.ua/operativ/operativ2017/tr/vp/vp_u/vp1217_u.htm [in Ukrainian].

2. Pasazhyrooborot ta kilkist perevezenykh pasazhyriv. Derzhstat Ukrainy [Passenger turnover and number of passengers transported. Gosstat of Ukraine]. ukrstat.gov.ua Retrieved from: http://www.ukrstat.gov.ua/operativ/operativ2017/tr/pp/pp_u/pp1217_u.htm. [in Ukrainian].

3. Transport. Derzhstat Ukrainy [Transport. Gosstat of Ukraine]. ukrstat.gov.ua Retrieved from: http://www.ukrstat.gov.ua/operativ/operativ2005/tz/tz_rik/tz_u/ts_u.htm. [in Ukrainian].

4. Statystychni dani pro Ukrainski zaliznytsi. Ministerstvo infrastruktury Ukrainy [Statistical data on Ukrainian railways. Ministry of Infrastructure of Ukraine] mtu.gov.ua Retrieved from: https://mtu.gov.ua/content/statistichnidani-pro-ukrainski-zaliznici.html. [in Ukrainian].

5. Statystychni dani $v$ haluzi aviatransportu. Ministerstvo infrastruktury Ukrainy [Statistics in the field of air transport. Ministry of Infrastructure of Ukraine] mtu.gov.ua Retrieved from: https://mtu.gov.ua/content/statistichnidani-v-galuzi-aviatransportu.html [in Ukrainian].

6. Krasnyuk M., Kustarovskiy O. (2017) The development of the concept and set of practical measures of anti-crisis logistics management in the current Ukraine conditions - Zarządzanie. Teoria i Praktyka 19 (1) 2017, Retrieved from: http://www.kaweczynska.pl/wydawnictwo/zarzadzanie-teoria-i-praktyka/zarzadzanie-teoria-i-praktyka-numer-

biezazy?download=5464:zarzadzanie-teoria-i-praktyka-management-theory-practice-4-18-2016. [in Poland].

7. Kravchuk L.S., Voienna K.I. (2012) Antykryzovyi menedzhment yak instrument nedopushchennia zahrozy bankrutstva [Anti-crisis management as a tool to prevent the threat of bankruptcy] Retrieved from: http://www.m.nayka.com.ua/?op=1\&j=efektyvna-ekonomika\&s=eng\&z=1089. [in Ukrainian].

8. Krasniuk M.T., Kustarovskyi O.D.. (2017) Problemy ta perspektyvy rozvytku ukrainskykh lohistychnoinformatsiinykh system $\mathrm{v}$ umovakh hlobalizovanoi ekonomiky ta makroekonomichnykh kryzovykh yavyshch [Problems and prospects of development of Ukrainian logistics and information systems in the conditions of a globalized economy and macroeconomic crisis phenomena] // Investytsii: praktyka ta dosvid-_Investments: practice and experience. №10: Chornomorskyi derzhavnyi universytet imeni Petra Mohyly-Black Sea State University named after Peter Mohyla, p. 34-40. [in Ukrainian].

9. Sudakova O.(2008) Lohistyzatsiia yak zasib zabezpechennia ekonomichnoi bezpeky pidpryiemstva [Logistics as means of ensuring the economic security of the enterprise] Skhid.-№ 3(87) [in Ukrainian].

10. Hapchak T.H (2010) Ryzyky v lohistychnykh protsesakh [Risks in logistics processes] Ekonomika: problemi teoriyi ta praktiki Retrieved from: http://uk.x-pdf.ru/6raznoe/159647-1-v-statti-analizu-tsya-zmist-prichini-viniknennyaneviznachenosti-logistichnih-sistemah-sistematizovano-klasifikaciyni.php. [in Ukrainian]. 